\title{
A critique of the Capability Approach's potential for application to career guidance
}

\author{
Valerie Egdell $^{1}$ (D) Peter J. Robertson ${ }^{2}$ iD
}

Received: 6 December 2019 / Accepted: 27 September 2020 / Published online: 16 October 2020

(c) The Author(s) 2020

\begin{abstract}
In this article, we provide a balanced critique of Sen's Capability Approach (CA) with reference to its potential to inform career guidance theory and practice. There are varying understandings and interpretations of the CA. Some see capabilities as universal, whilst others favour a more relativist view. The CA is also vulnerable to misunderstanding. Critiques based on misunderstanding are easily dismissed, so our focus is on substantive conceptual and practical critiques. Three main challenges are explored: conceptual debates about the nature of freedom and justice; limitations arising from the disciplinary origins of the $\mathrm{CA}$; and challenges in operationalising the CA.
\end{abstract}

Keywords Capability Approach · Career guidance · Career theory

\section{Résumé}

Une Critique du Potentiel de l'Approche des Capacités pour les applications au conseil de carrière Dans cet article, nous produisons une critique de l'Approche des Capacités $(\mathrm{AC})$ de Sen en référence à son potentiel pour informer la théorie et la pratique du conseil de carrière. Il y a plusieurs compréhensions et interprétations de l'AC. Certains voient les capacités comme étant universelles, pendant que d'autres favorisent une vue plus relativiste. L'AC est aussi vulnérable aux incompréhensions. Les critiques basées sur des incompréhensions sont facilement rejetées, donc nous nous concentrons sur les critiques substantielles conceptuelles et pratiques. Trois challenges principaux ont été explorés: des débats conceptuels sur la nature de la liberté et de la justice; des limitations découlant des origines disciplinaires de l'AC; et des challenges dans l'opérationalisation de l'AC.

Valerie Egdell

valerie.egdell@northumbria.ac.uk

1 Newcastle Business School, Northumbria University, City Campus East, Newcastle upon Tyne NE1 8ST, UK

2 School of Applied Sciences, Edinburgh Napier University, Edinburgh, UK 


\section{Kurzfassung}

Eine kritische Betrachtung der Anwendung des Befähigungsansatzes in der Berufs-, Studien- und Laufbahnberatung Dieser Artikel beinhaltet eine kritische Betrachtung des Befähigungsansatzes (Capability Approach, CA) von Sen in Bezug auf sein Potential, Theorie und Praxis der Berufs-, Studien- und Laufbahnberatung $\mathrm{zu}$ beeinflussen. Es gibt unterschiedliche Auffassungen und Interpretationen des Befähigungsansatzes. Einige betrachten den Ansatz als universell, während andere eine eher relativistische Sichtweise bevorzugen. Der Befähigungsansatz ist auch anfällig für Missverständnisse. Kritik, die auf Missverständnissen beruht, kann aber leicht zurückgewiesen werden, weshalb wir uns auf die konzeptionelle und anwendungsbezogene Kritik konzentrieren. Dabei werden drei Hauptherausforderungen beleuchtet: Konzeptionelle Debatten über das Wesen von Freiheit und Gerechtigkeit; Einschränkungen, die sich aus dem disziplinären Ursprung des Befähigungsansatzes ergeben; Herausforderungen bei der Operationalisierung des Befähigungsansatzes.

\section{Resumen}

Una crítica del potencial del Enfoque Basado en las Capacidades aplicado a la orientación profesional En este artículo proporcionamos una crítica equilibrada del Enfoque Basado en las Capacidades de Sen (CA) en referencia a su potencial para informar la teoria y la práctica de la orientación profesional. Existen diferentes interpretaciones y maneras de comprender este enfoque (CA). Algunas consideran las capacidades como universales al tiempo que otras se acercan más a una visión relativista. El CA es también vulnerable a equívocos y errores de comprensión. Las críticas basadas en los errores de comprensión son facilmente desestimadas por lo que nuestro foco se sitúa en las críticas conceptuales y prácticas. Se exploran tres desafíos principales: debates conceptuales sobre la naturaleza de la libertad y la justicia, limitaciones que emergen de los orígenes disciplinares del CA y retos en la operacionalización del CA.

\section{Introduction}

The Capability Approach (CA) is a way of thinking about the promotion of wellbeing and freedom and originates in the thinking of economist and philosopher Amartya Sen $(1985,1990,1999,2003,2009)$. While it has its origins in welfare economics, it has been applied to many domains, notably educational and economic advancement in developing nations (Kelly, 2012; Norwich, 2014; Orton, 2011; Otto et al., 2015, 2017; Picard et al., 2015; Skovhus, 2016). Authors have sought to apply the $\mathrm{CA}$ as a theoretical perspective to describe career development experiences or to understand processes of career guidance (e.g. Picard, 2019; Robertson, 2015; Robertson \& Egdell, 2018). Indeed, there now exist a wide range of theories of career choice and development with numerous recent contributions to this literature. However, in our view, contemporary career theory has tended to lack criticality (with some notable exceptions that are discussed in the next section). This literature 
has tended to present multiple theories without critique (e.g. Arthur et al., 2019), or has attempted theoretical integration (e.g. McMahon \& Patton, 2018) with the effect that the limitations of one perspective are compensated for by the strengths of another. Criticality in this literature is primarily directed against historic targets, demonstrating the 'superiority' of dynamic contemporary theory over static twentieth century models in addressing issues of the volatility of work (e.g. Pryor, 2016; Savickas et al., 2009). It is relatively rare that contemporary career theorists systematically explore the limitations of their own theories or those of their peers.

Thus, in this article we offer a critical perspective on the CA and its potential for application to career guidance. We are concerned not just with theory but also with practice, by which we mean attempts by practitioners to improve people's lives by intervening in their career development, irrespective of the professional identity or institutional setting. There are a range of authors who have developed the CA, including Nussbaum (1997, 2000, 2003), so there is some variety of thinking within the literature. Whilst acknowledging this diversity, we focus our critical perspective primarily on the CA as conceived by Sen.

A number of critiques and debates are explored. The CA has been vulnerable to misunderstanding, which can result in a superficial reading and dilution in its application (Kremakova, 2013; Sayer, 2012). Critiques based on misunderstanding are easily dismissed, so our focus is on substantive conceptual and practical critiques. This material is organised into three sections. Firstly, the CA can be understood as one of a number of philosophical positions on issues of freedom and justice. Although these debates are relatively abstract, issues of social justice and the freedom to make life choices are of direct relevance to career guidance practice. Secondly, unlike most career theory, which originates in psychology or sociology, the CA has its roots in economics. The limitations of its disciplinary origins can be critiqued from the perspective of other social science disciplines. Thirdly, there are considerable difficulties in operationalising the CA. The distance from the concept to practice is considerable, generating a range of questions to be addressed. In each section we seek to make the debates relevant to the concerns of career guidance, and identify where a reasonable defence of the CA can be made, and where there are limitations in what it has to offer to career theory and guidance. We are also mindful that the CA was not initially intended to be applied, or offer applications, to career theory and guidance. It is easy to identify the limits of a theoretical perspective constructed in another discipline. Consequently, we emphasise that our purpose is not to critique the CA for critiques sake. Rather we seek to explore how the CA may be applied in practice, and areas where it may need to be theoretically and empirically developed to make it relevant for career guidance.

\section{Conceptual debates about the nature of freedom and justice}

There is a prominent and long-established social justice and egalitarianism agenda within the career guidance field. The promotion of social equity is seen as one of the prime aims of public policy in relation to career guidance (Watts \& Sultana, 2004). Indeed, in recent years there has even been explicit debate regarding issues of social 
justice in the academic and professional literature (Hooley \& Sultana, 2016). This has included a focus on the contested (political and philosophical) nature of social justice. Some contributors have sought inspiration to address modern injustices in the work of early pioneers of vocational guidance, who were social activists with collectivist values (Plant \& Kjærgård, 2016). Many have explored ways to respond to the career issues facing specific populations who might be characterised as socio-economically disadvantaged (e.g. Bimrose et al., 2019; Ginevra et al., 2019; Hancock \& Taylor, 2019; Newman et al., 2018), or have addressed issues of poverty, class, and precarity (e.g. Ali, 2014; Blustein, 2019; Roberts, 2005). Others have sought to suggest strategies or tools for career development professionals to adopt (e.g. Arthur, 2005; Kenny et al., 2019; Thomsen, 2016) or have offered a call to emancipatory action (Blustein, 2019; Hooley et al., 2019). This diverse literature has explicitly sought to bring a critical perspective to current theories, institutions and practices, and the extent to which they are infused by culturally dominant neoliberal economic assumptions that limit freedom as it is expressed in careers (Hooley et al., 2017).

In exploring the contested relations between social justice and career guidance, scholars have pointed to a range of philosophical approaches. These include the ancient philosophy of Socrates and Plato emphasising social harmony; the Kantian tradition emphasising rights; the ethical/relational perspective of Levinas and Derrida; and 'recognitive justice' inspired by Young that acknowledges oppression of groups in society (Irving, 2004, 2020; Sultana, 2014). Irving (2004, 2020) and Sultana (2014) acknowledge the relevance of John Rawls' theory of justice which offers a 'distributive justice' or 'resourcist' approach; but do not foreground the work of Amartya Sen. This is curious because Sen's CA is located in an arena of conceptual debate regarding egalitarian theories of social justice and the nature of freedom and justice. Sen $(1985,1990,2003)$ evens acknowledges the influence of Rawls on his work. Comparing a full range of social justice concepts is beyond the scope of this article. Instead we highlight a key debate in the literature regarding the nature of freedom and justice.

Egalitarian theory contends that institutions and individual actions should improve the quality of life of those who are worse off in society (Y1lmaz, 2016). There are two prominent examples of egalitarian theories of social justice, addressing the key question of what is a proper measure of social justice-and an extensive literature questioning which of these is able to provide the most convincing yardstick of social justice (Pogge, 2002). These two approaches are the resourcist approach (developed by authors including Rawls (1999) and Dworkin (1981a, 1981b) and the CA (developed by authors including Sen (1985, 1990, 2003) and Nussbaum (1997, 2000, 2003) (Y1lmaz, 2016). The criterion presented by Rawls (1999) and Sen $(1985,1990,2003)$ are focused upon here.

Rawls' (1999) theory of justice emphasises equal basic liberties and just equality of opportunity. The Rawlsian principles of justice are that "each person is to have an equal right to the most extensive total system" and that social and economic inequality are arranged so that they are "(a) to the greatest benefit of the least advantaged, consistent with the just savings principle, and (b) attached to offices and positions open to all under conditions of fair equality of opportunity" 
(Rawls, 1999, p. 266). The focus is on the holding of 'primary goods' (including income, rights, a sense of self-worth and opportunities), defined as things that it is presumed that every "rational man" wants whatever their plans are (Rawls, 1999, p. 54). However, these primary goods answer the needs of individuals rather than their desires and preferences (Rawls, 1999) and attention is not paid to how individuals use these resources (Y1lmaz, 2016).

Conversely capabilities scholars focus on fundamental diversity; understanding that while two individuals may hold the same primary goods, they have different freedoms to live a life that they have reason to value (Sen 1985, 1990, 2003). Sen $(1990,2003)$ argues that to judge equality in terms of primary goods (i.e. a Rawlsian principle of justice) gives priority to the 'means' of freedom rather than the 'extents' of freedom. As such capabilities are the combinations of functionings and the real (not just formal and/or 'in principle' freedoms) opportunity to achieve them (Sen, 2003). This distinction is crucial to understand the contribution of conversion factors including social conditioning which may make an individual unable to choose (Robertson \& Egdell, 2018; Sen, 2003). In acknowledging the influence of social relations as well as the societal and institutional structures, the CA rejects methodological/ontological individualism (Robeyns, 2005). The CA does however embrace ethical individualism i.e. claims "about who or what should count in our evaluative exercises and decisions. It postulates that individuals, and only individuals, are the units of moral concern. In other words, when evaluating different states of social affairs, we are only interested in the (direct and indirect) effects of those states on individuals" (Robeyns, 2005, p. 107).

For career guidance, this may be an important distinction when considering gender inequalities for example. The existence of rights to equal pay supported by legislation has not removed gender inequality in pay (Fortin et al., 2017; O'Reilly et al., 2015). Similarly, the right to pursue any occupation without discrimination does not remove the possibility that in practice women may be subject to sexual harassment from both colleagues and customers (Equality and Human Rights Commission, 2018). Thus, a CA to career guidance theory and practice goes beyond a resourcist position that justice in women's careers requires only equal rights and adopts a stance more consistent with a stronger feminist position. It also acknowledges that real life practical barriers must be overcome for capabilities to be equal.

Taking this example of workplace gender equality further, the CA might stop short of requiring that justice necessarily means symmetrical functioning in all situations, if it was the case that individual men and women had reason to value different lives and careers, and in consequence, made different choices. The emphasis of the CA is upon the freedom that individuals have to make choices that they value, and the importance of individuals not having values imposed on them regarding what is a 'good' life (Sen, 1985, 1990, 2003). Equality of freedom cannot be achieved through the equal distribution of primary goods, nor can it measure well-being when it does not acknowledge interpersonal variations in the transformation of primary into capabilities (Sen, 1985, 1990, 2003). As such the CA frames justice in terms of capabilities to function i.e. ends rather than means 
and reflects substantive freedom to achieve well-being (Sen, 2003; Y1lmaz, 2016). A distinction is drawn between the functionings space (beings and doings) and the capabilities space (all that the individual can be and do) (Sen, 2003).

Thus, while resourcists argue that the resources that people need should be distributed, proponents of the CA emphasise the equalisation of people's capabilities (Y1lmaz, 2016). A distinction is also made in terms of whether "alternative feasible institutional schemes [should] be assessed in terms of their participants' access to available resources or in terms of their participants' capabilities, that is, access to valuable functionings" (Pogge, 2002, p. 178). As such the metric of justice proposed by Rawls (1999) are primary goods. The emphasis is on an understanding of 'standard' needs rather than the value attached to these goods by reference to the specific needs and attributes of the individual (Pogge, 2002). The Rawlsian approach is focused on just institutions and underpinned with ideas of public consensus (although privately citizens may hold opposing views). Conversely the CA emphasises just societies and shared conceptions of good in society (Y1lmaz, 2016). Yet, the distinction between the CA and resourcists may not be so stark as first appears, with some arguing that resourcists focus not on the goods persons actually have or consume, but on the goods persons can have or consume (Pogge, 2002). Certainly, as mentioned previously, Sen (1985, 1990, 2003) acknowledges the influence of Rawls on his work. Equally, resourcist and capability theorists agree regarding the purpose of the distribution of means in terms of satisfying human needs and the of positive freedom (Y1lmaz, 2016).

In summary, Sen's $(1985,1990,2003)$ CA entered an arena of conceptual debate about the nature of freedom and justice. Competing philosophies offer alternatives to the CA. Career guidance theory and practice needs to navigate these relatively abstract debates; including the adequacy of resources in achieving freedom and the tensions between individual and collective or community values, and the implications of this problem for freedom. Contemporary debates of the nature of social justice in the career guidance literature has acknowledged the work of Rawls but not that of Sen (e.g. Irving, 2004, 2020; Sultana, 2014). While the differences between Sen's approach and a Rawlsian perspective should not be overstated, the CA does ensure that the pragmatic challenges of converting resources into lifestyle outcomes are not neglected.

\section{Limitations arising from the origins of the Capability Approach}

The disciplinary origins of the CA potentially limit its contribution to understanding careers and career guidance. Sen's CA emerged from critiques of mainstream economics focusing solely on growth measures, resources, and the actions of rational individuals (e.g. Sen, 1999). Its roots are thus primarily in economics. In contrast, the study of careers is best understood as a transdisciplinary field in which a wide range of perspectives intersect. Whilst (labour market) economics is one discipline; it is not the prime source for theory and practice. Psychology is the dominant discipline in career theory, while sociology makes an important contribution to career theory and to career-related policy analysis. There are few explicit links to 
psychology and sociology in Sen's work, with the CA's reputation for a being a normative tool for policy research and practice, rather than an explanatory tool for critical social theory, partly explaining this (Kremakova, 2013). The CA's neglect of sociology is rooted in the troubled relationship between the discipline and economics (Holmwood, 2013). However, some sociologists such as Hart (2012) demonstrate congurence between the work of Sen and Bourdieu. In terms of the practice of delivering career services, education, counselling, social work and youth work are strong influences.

There can be no doubt that Sen's work demonstrates a central concern for those living in poverty and seeks to extend the opportunities disadvantaged groups have to implement choices about their lives according to their own values. While Sen (2003, 2009) distances the CA from utilitarianism and mainstream economics, critics suggest that Sen's work is infused with liberal-individualism (e.g. Carpenter, 2009). It has been argued that the 'elephant in the room' is that the CA does not address the exploitative nature of capitalism. The individual is abstracted and removed from relations of power and capitalist structures of domination that give meaning to individual freedom (Dean, 2009; Gasper, 2002; Sayer, 2012). Welfare economics is rooted in ideas that are market-oriented and evangelises market-based solutions. It is therefore at odds with sociology which defends against the tyranny of the market (Burawoy, 2005; Holmwood, 2013).

These concerns are mirrored in the career guidance literature, with authors such as Hooley et al. (2017) raising objections to the way in which neoliberal thinking has infused career guidance policy. Neoliberal welfare states focuses upon raising selfinitiative and do not account for either contextual constraints, nor individual choice (Egdell \& McQuaid, 2016; Wright, 2016)—which is at odds with the CA. Irving $(2017,2020)$ characterises the neoliberal perspective (in the tradition of Friedman) as 'retributive justice' in which economic freedom and property rights underpin a free market. This author advocates a critical perspective of the status quo, combined with a radical educational approach to raising consciousness in response to injustice and inequality in careers. Whether a CA could serve to meet these calls can be questioned. There is a tendency for the CA to focus on 'minimum thresholds' and limited state intervention, rather than more radical equality of outcomes (Carpenter, 2009). However, it is argued that the CA could be combined with understandings of power and class in ways that would provide support for conclusions so radical that "policy makers and advisors who favour the Capability Approach would find alarming" (Sayer, 2012, p. 583). Albeit the structural external constraints on the achievement of inequalities need to be addressed in order that these radical implications are realised (Sayer, 2012). The individualist tendencies perhaps reflect a mismatch between the bold aims of the CA and means to realise them, with Carpenter (2009) suggesting developing a radical CA through a connection with fuller political economic and social analysis.

Critique of the CA's liberal-individualist focus also draws attention to the limited acknowledgement of social solidarity and belonging. Several authors argue that the CA is flawed as it does not account for the interdependency of humans, and overemphasises rational cognitive action (e.g. Dean, 2009; Deneulin \& McGregor, 2010; Iversen, 2003; Zimmermann, 2006). Individuals only exist because they are 
members of networks of care and responsibility, dependent on others (Kittay, 2001; Sevenhuijsen, 1998). While Nussbaum (1997, 2000, 2003) develops a list of central interrelated capabilities which includes 'affiliation'; this has been argued to be abstract, with the 'person' and 'the other' framed as abstract bearers of capabilities (Dean, 2009, p. 268). This critique has direct relevance, as some authors highlight the relational nature of career development and place this aspect as central to their conception of career guidance (Blustein, 2011, 2019; Richardson, 2009). These perspectives do not privilege formal paid employment over other kinds of work and relationships. Others have pointed to the potential for a community level conception of career guidance (notably Thomsen, 2012). The CA is not inconsistent with this project. Whilst ultimately concerned with the well-being and freedom of individuals, it does allow for community level applications (Alkire, 2005; Alkire \& Deneulin, 2009).

Taking this issue of interdependency further, the ways in which we care for each other are socially negotiated and consolidated over time (Connidis, 2001; Finch \& Mason, 1993) but the time dimension is lacking in the CA (Gasper, 1997). This is problematic as biographies develop over a working life, and careers can only be understood looking backwards and projecting forwards (Robertson, 2015; Zimmerman, 2006). Here we move to a psychological critique. Perspectives on maturation derived from developmental psychology (notably Gottfredson (1981) and Super (1957)) conclusively demonstrate the inadequacy of considering career choice as anything other than a process which unfolds over time. Yet this dynamic conception is entirely absent the CA. Joncas and Pilote (2018) suggest a solution to this problem-viewing the conversion of career resources into capabilities and functionings as an iterative process, rather than as a single point in time.

There is also critique of the CA in terms of it not providing any substantive discussion of choice processes, what brings individuals satisfaction or any theory of 'good' (Gasper, 1997, 2002). The skills, personality formation and social supports required in making decisions about what is valuable is not elaborated upon (Gasper 2002) which present challenges for those wishing to apply the CA to career guidance practice. Sen (2009) does question the concept of rationality within economics. Unlike its parent discipline, the CA does not routinely adopt money as a proxy for 'good', or view maximising income as the only rational strategy. In rejecting methodological/ontological individualism the links between individuals and society are highlighted (Robeyns, 2005). Neither does the CA see values purely as an individual difference variable as might be the case in some psychological conceptions (e.g. Schein, 1990). It places human values as central to choice and allows for thoughtful trade-offs between them. 'Reason to value' implies a process of reasoning prior to choice but no insight as to how that process might work is provided.

A key challenge here for career guidance is that, the freedom of individuals and groups to reason about the life chances open to them, is powerfully shaped by a range of social, cultural and economic factors as demonstrated by structural theorists (notably Roberts (2009)). Furthermore, these are not simply experienced as external barriers, but become internalised as constraints on choices in the thinking of individuals (Betz \& Hackett, 2006; Gottfredson, 1981; Hodkinson \& Sparkes, 
1997; Willis, 1977). To an extent, Sen recognises this problem in that he is critical of the use of subjective measures of well-being (at least if used in isolation) because people living in relative deprivation habituate to their circumstances (Binder, 2013; Sen, 1987). It is less clear if he recognises the impact of deprivation on choice reasoning processes, and the implications that this has for just outcomes. This raises questions as to whether at the empirical level Sen is in fact fixated with 'generic' and 'rational' individuals (Zimmermann, 2006, p. 474). Adding more choices may be undesirable as excessive choice may distract, distort and divert (Gasper, 2002). Sen's (2009) argument for the role of public deliberation in developing capabilities lists, may only to serve to exacerbate the problem, and be framed by normative liberal assumptions about who the 'public' are (Dean, 2009). Even Nussbaum's (1997, 2000,2003 ) richer elaboration of the CA is incomplete compared to understandings from psychology as to what brings people satisfaction and well-being, nor does it differentiate between types of pleasure and happiness (Gasper, 2002).

In summary, while it could be argued that the CA offers a fresh perspective on careers by virtue of deriving from economics, economics is suffused with liberal-individualism. To a certain extent, the same critique can be levelled at the contemporary policy and practice of career guidance (Hooley et al., 2017; Irving, 2017, 2020). While Sen (2009) does problematise the concept of rationality, the CA nevertheless does not account for human interdependency (Dean, 2009; Deneulin \& McGregor, 2010; Iversen, 2003; Zimmermann, 2006) and does not offer the temporal dimension required to understand how biographies unfold (Robertson, 2015; Gasper, 1997; Zimmerman, 2006). As such the CA may not be sufficiently equipped to provide a sociological analysis of inequality in careers, or a psychological description of career choice processes.

\section{Challenges in operationalising the Capability Approach for career guidance practice}

The abstract nature of the CA (some of which is highlighted in the previous sections) presents challenges to career guidance practitioners seeking to operationalise it for the development and evaluation of their interventions. For the purposes of career guidance, it is necessary to specify what kinds of resources people may have. There are existing resource models for career development (notably Hirschi, 2012) but these tend to focus primarily on individual psychological factors, whilst the CA would also require consideration of wider economic, social and environmental resources. It would also require identifying how resources may be converted into realistically attainable opportunities, how choices are made, and the kinds of outcomes that may be obtained. To achieve this, the processes of assessment and measurement need to be made explicit. However, the operationalisation of the CA in this way is challenging because of the complexity, context dependency and its under-specificity (Chiappero-Martinetti et al., 2015; Robertson \& Egdell, 2018; Robeyns, 2008; Roemer, 1996; Srinivasan, 1994).

A key critique of levelled at Sen is that in his presentation of the CA no defined central human capabilities and functionings, or explanation of how these should be 
weighted against each other, are offered. Sen's rationale for this is that any definition of what people value should be open to diverse conceptions of good, justice and advantage, and reflect that capabilities lists are used for different purposes (Robeyns, 2005; Sen, 2009). Equally, there is no such agreed framework to identify 'results' and evaluate career guidance practice; outcomes are conceptualised in a variety of ways (Killeen, 1996). Guidance is provided for the development of context specific lists in the application of the CA (Burchardt \& Vizard, 2007). Sen has, since the first inceptions, developed his argument as to how the CA might be applied, moving from a 'thin view' which solely argues the case for capability and functioning as evaluative spaces, to a 'thick view' which accounts for the evaluative implications of applying the CA (Qizilbash, 2011; Sen, 1999, 2009). However, the lack of specified capabilities, functionings and weightings mean that Sen's CA remains underspecified and incomplete (Qizilbash, 2011; Robeyns, 2008). This makes it flexible in its application across contexts, but is arguably a relativist position, and one that can be adapted to justify a range of actions.

Serious consideration would need to be made if a capabilities list were developed for career guidance. Nussbaum (1997, 2000, 2003) develops a list of ten central interrelated capabilities (bodily health; bodily integrity; senses, imagination and thought; emotions; practical reason; affiliation; other species; play; and control over one's environment) which are in turn categorised into three capability types: (1) basic capabilities (essential requirements to develop more advanced capabilities); (2) internal capabilities (conditions of the individual); and (3) combined capabilities (internal capabilities and the external conditions in the exercise of functionings) (Nussbaum, 2000, pp. 78-80, 84-85). However, Pogge (2002, p. 210) questions the value of capability lists, and the equitability of their application, as it would involve "grading all citizens for their natural aptitudes toward each of the capabilities on the list, determining their specific deficits, and ensuring that these deficits are duly neutralized through suitable compensatory benefits". Specificity is also required by career development practitioners rather than broad-brush higher-level descriptive frameworks like Nussbaum's (Robertson \& Egdell, 2018). Context sensitivity would also be important. In the generation and/or selection of such a distinct career focused list, public discussion and debate would be required to understand what people do have reason to value (Sen, 2009). This public deliberation is achieved through the 'informational basis of the judgement of justice' (IBJJ), that is the information framed as relevant by actors when considering a situation (Sen, 1985, 1990, 2003). This deliberation is open ended and multiple IBBJs may co-exist (Kremakova 2013). Public discussion and debate could serve as a way in which to address the problem of adaptive preference formation (Qizilbash, 2011); that is situations where inequality in circumstances results in individuals internalising conceptions of their own self-worth (Nussbaum, 1997, 2000).

However, there are concerns that public discussion and debate could result in paternalism, with democratic reasoning overriding individual preferences and placing restrictions on individual liberty (Sugden, 2006). Such a view would present career guidance practitioners with complex questions surrounding the appropriateness of enhancing any capability. A society must acknowledge various distinct liberties and freedoms, but must prioritise them, in a democratic way, 
when they conflict (Qizilbash, 2011). As such individual client judgement needs to be developed so that they can value in which way it is appropriate and avoid any abuse of capabilities (Saito, 2003). Added to this, even if a distinct career focused list were agreed, the list and the weightings given to the value of each functioning, would not be static to reflect changing societal priorities over time (Qizilbash, 2011). However, the public deliberation aspect makes the CA distinct and offers a way in which to operationalise the approach (Sen, 2009). In this work, service user capability for voice would need to be developed; that is "their effective possibility to express their concerns with regard to the choice of the informational basis" (Bonvin \& Farvaque, 2005, p. 269). The capability for voice concept bridges the gap between subjective preferences and objective assessment in evaluation.

In terms of evaluating a CA to career guidance there are further limitations that would need to be overcome. Evaluation underpins evidence-based practice in career guidance: it is therefore important, but it is also problematic. A range of approaches are available (Hooley, 2014; Killeen, 1996). Some use objective measures of career outcomes, such as salary; others use subjective measures, such as job satisfaction. Criteria may be economically or employment focused, but they may also conceptualise career development as an educational experience and therefore adopt learning outcomes (Killeen \& Kidd, 1991). Some prefer psychological measures of attitudinal change or quasi-clinical measures of well-being related variables. Easy to measure variables tend to be preferred, although they may not offer the most insightful approach, and service user's perspectives are often neglected (Plant, 2012; Plant \& Haug, 2018), particularly in the consideration of deeper and strategic issues, such as how service outcomes are defined and prioritised. The challenges of evaluating career guidance are considerable, and the CA implies that career capabilities are the desirable focus. On the one hand this opens-up a fresh way of conceptualising the outcomes of career guidance-by assessing the capability set: the range of realistically attainable lives/careers that can genuinely be accessed (Sen, 1985, 1990, 2003). On the other hand, this creates new problems. Whilst unrealised potentialities are intriguing, they are difficult if not impossible to capture for the purposes of evaluation. Furthermore, career guidance is not necessarily complete if a range of opportunities have been opened-up. It also serves to help people choose one path among many i.e. in the language of the CA, to select the functioning that they have reason to value (Sen, 1985, 1990, 2003). Sen (2003) does however offer the practical compromise, whereby observations of capability are constructed based on presumptions, relating well-being to the achieved and observed functionings, rather than the capability set.

A final key issue in evaluating career guidance is consideration of the level of analysis to be used. A 'good' result might be understood at a micro (individual), meso (group/organisation), or macro (societal) level (Killeen, 1996). Whilst individual level analysis tends to be given primacy, it is important to recognise the potential for career guidance to be a community level intervention (Thomsen, 2012), and the potential for conceptualising capabilities at this meso level. In pursuing this route, the issue of public deliberation becomes particularly salient. All the issues explored in this section have ethical implications for practitioners. The CA to career 
guidance would suggest that autonomy is a central ethical principle for practice (Robertson \& Egdell, 2018), and that career choices are to be understood as valuesbased. Ethical problems and dilemmas may arise where there are clashes between the priorities of individuals, communities, practitioners, and career services. Whilst debate and discussion may go some way towards reconciling these differences, some conflict of values may be unavoidable.

In summary, the key question for career guidance, arising from the issue of evaluation, is whether capabilities can be measured. There are arguments that only functionings can be measured, as substantive freedoms and opportunities cannot be observed, only deduced (Chiappero-Martinetti et al., 2015; Verd \& Andreu, 2011; Zimmermann, 2006). Indeed, at the theoretical application level, the blurring of the boundaries in the CA between options and capabilities are highlighted (Gasper, 2002). As such there are difficulties when operationalising the CA for the real world in measuring capabilities separately from functionings (Walby, 2012). The mutual dependency of capabilities, functioning and conversion factors add another layer of complexity (Kremakova, 2013, p. 403). Added to this service users may not be used to expressing their views and may find it hard to answer the open questions required to identify the benefits of capability informed career guidance interventions (Chiappero-Martinetti et al., 2015).

\section{Conclusions}

Having examined these three groups of challenges, it is concluded that the CA stands up well to conceptual critiques, provided the claims made for it are moderate. It offers a distinctive philosophical approach to social justice, but clearly not the only possible approach. The differences between Sen's approach and a Rawlsian perspective should not be overstated (Pogge, 2002; Rawls, 1999; Sen, 1985, 1990, 2003; Y1lmaz, 2016), but the CA does ensure that the pragmatic challenges of converting resources into lifestyle outcomes are not neglected. It offers a fresh approach to thinking about careers by virtue of deriving from economics, but in common with its parent discipline, it is not equipped to provide an adequate sociological analysis of inequality in careers, or a psychological description of career choice processes (Carpenter, 2009; Dean, 2009; Gasper, 2002; Kremakova, 2013; Robertson, 2015; Sayer, 2012; Zimmerman, 2006). Nonetheless, the CA may provide a frame within which transdisciplinary dialogue about career development can take place.

It presents practical challenges in making the leap from theory to practice, leaving many difficult choices for the practitioner in terms of identifying resources, conversion factors, and outcomes (Chiappero-Martinetti et al., 2015; Robertson \& Egdell, 2018; Verd \& Andreu, 2011; Walby, 2012; Zimmermann, 2006). It offers a new angle on assessment, evaluation, and service user involvement, but offers few guidelines on meeting these challenges. "The problem is that even though such an approach develops a challenging attempt to conceptualize freedom with regard to public action, it provides neither a theory of society nor a methodology of inquiry, 
dimensions that are both required for sociological investigation" (Zimmermann, 2006, p. 469).

Its fundamental limitation as an approach to career guidance is its incompleteness. It can stimulate thinking, but only by combining the approach with psycho-social perspectives on careers can an adequate understanding be achieved. Given the diversity of career development concepts now available it seems likely that a variety of hybrid approaches are possible. Thus, there may be no single CA to career guidance, but the potential for a diversity of models for practice sharing a common starting point, inspired by the work of Sen.

Funding The authors received no specific funding for this work.

\section{Compliance with ethical standards}

Conflict of interest The authors declare that they have no conflict of interest.

Open Access This article is licensed under a Creative Commons Attribution 4.0 International License, which permits use, sharing, adaptation, distribution and reproduction in any medium or format, as long as you give appropriate credit to the original author(s) and the source, provide a link to the Creative Commons licence, and indicate if changes were made. The images or other third party material in this article are included in the article's Creative Commons licence, unless indicated otherwise in a credit line to the material. If material is not included in the article's Creative Commons licence and your intended use is not permitted by statutory regulation or exceeds the permitted use, you will need to obtain permission directly from the copyright holder. To view a copy of this licence, visit http://creativeco mmons.org/licenses/by/4.0/.

\section{References}

Ali, S. R. (2014). Poverty, social class and working. In D. L. Blustein (Ed.), The Oxford handbook of the psychology of working (pp. 127-140). Oxford University Press.

Alkire, S. (2005). Why the capability approach? Journal of Human Development, 6(1), 115-135. https:// doi.org/10.1080/146498805200034275.

Alkire, S., \& Deneulin, S. (2009). The human development and capability approach. In S. Deneulin \& L. Shahani (Eds.), An introduction to the human development and capability approach: Freedom and agency (pp. 22-48). Earthscan

Arthur, N. (2005). Building from diversity to social justice competencies in international standards for career development practitioners. International Journal for Educational and Vocational Guidance, 5(2), 137-140. https://doi.org/10.1007/s10775-005-8791-4.

Arthur, N., Neault, R., \& McMahon, M. (Eds.) (2019). Career theories and models at work: Ideas for practice. CERIC.

Betz, N. E., \& Hackett, G. (2006). Career self-efficacy theory: Back to the future. Journal of Career Assessment, 14(1), 3-11. https://doi.org/10.1177/1069072705281347.

Bimrose, J., McMahon, M., \& Watson, M. (2019). Women and social justice: Does career guidance have a role? In T. Hooley, R. Sultana, \& R. Thomsen (Eds.), Career guidance for emancipation: Reclaiming social justice for the multitude (pp. 17-32). Routledge.

Binder, M. (2013). Subjective well-being capabilities: Bridging the gap between the capability approach and subjective well-being research. Journal of Happiness Studies, 15(5), 1197-1217. https://doi. org/10.1007/s10902-013-9471-6.

Blustein, D. L. (2011). A relational theory of working. Journal of Vocational Behavior, 79(1), 1-17. https ://doi.org/10.1016/j.jvb.2010.10.004. 
Blustein, D. L. (2019). The importance of work in an age of uncertainty: The eroding work experience in America. Oxford University Press.

Bonvin, J. M., \& Farvaque, N. (2005). What informational basis for assessing job-seekers?: Capabilities vs. preferences. Review of Social Economy, 63(2), 269-289. https://doi.org/10.1080/0034676500 130614

Burawoy, M. (2005). For public sociology. American Sociological Review, 70(1), 4-28. https://doi. org/10.1177/000312240507000102.

Burchardt, T., \& Vizard, P. (2007). Definition of equality and framework for measurement: Final recommendations of the equalities review steering group on measurement. CASEpapers (120). Centre for Analysis of Social Exclusion, London School of Economics and Political Science.

Carpenter, M. (2009). The capabilities approach and critical social policy: Lessons from the majority world? Critical Social Policy, 29(3), 351-373. https://doi.org/10.1177/0261018309105175.

Chiappero-Martinetti, E., Egdell, V., Hollywood, E., \& McQuaid, R. (2015). Operationalisation of the capability approach. In H.-U. Otto, R. Atzmüller, T. Berthet, L. Bifulco, J.-M. Bonvin, E. Chiappero-Martinetti, V. Egdell, B. Halleröd, C. C. Kjeldsen, M. Kwiek, R. Schröer, J. Vero, \& M. Zieleńska (Eds.), Facing trajectories from school to work-Towards a capability-friendly youth policy in Europe (pp. 115-139). Springer.

Connidis, I. (2001). Family ties and aging. Sage.

Dean, H. (2009). Critiquing capabilities: The distractions of a beguiling concept. Critical Social Policy, 29(2), 261-278. https://doi.org/10.1177/0261018308101629.

Deneulin, S., \& McGregor, J. A. (2010). The capability approach and the politics of a social conception of wellbeing. European Journal of Social Theory, 13(4), 501-519. https://doi.org/10.1177/13684 31010382762 .

Dworkin, R. (1981a). What is equality? Part 1: Equality of welfare. Philosophy \& Public Affairs, 10(3), 185-246. https://www.jstor.org/stable/2264894

Dworkin, R. (1981b). What is equality? Part 2: Equality of resources. Philosophy \& Public Affairs, 10(4), 283-345. https://www.jstor.org/stable/2265047

Egdell, V., \& McQuaid, R. (2016). Supporting disadvantaged young people into work: Insights from the capability approach. Social Policy \& Administration, 50(1), 1-18. https://doi.org/10.1111/ spol.12108.

Equality and Human Rights Commission. (2018). Turning the tables: Ending sexual harassment at work. Equality and Human Rights Commission.

Finch, J., \& Mason, J. (1993). Negotiating family responsibilities. Tavistock/Routledge.

Fortin, N. M., Bell, B., \& Böhm, M. (2017). Top earnings inequality and the gender pay gap: Canada, Sweden, and the United Kingdom. Labour Economics, 47(August 2017), 107-123. https://doi. org/10.1016/j.labeco.2017.05.010

Gasper, D. (1997). Sen's capability approach and Nussbaum's capabilities ethic. Journal of International Development, 9(2), 281-302. https://doi.org/10.1002/(SICI)1099-1328(199703)9:2\%3c281:AIDJID438\%3e3.0.CO;2-K.

Gasper, D. (2002). Is Sen's capability approach an adequate basis for considering human development? Review of Political Economy, 14(4), 435-461. https://doi.org/10.1080/0953825022000009898.

Ginevra, M. C., Santilli, S., Nota, L., \& Soresi, S. (2019). Interventions for career construction and work inclusion of individuals with disability. In T. Hooley, R. Sultana \& R. Thomsen (Eds.), Career guidance for emancipation: Reclaiming social justice for the multitude (pp. 33-46). Routledge.

Gottfredson, L. S. (1981). Circumscription and compromise: A developmental theory of occupational aspirations. Journal of Counseling Psychology, 43(1), 545-579. https://doi. org/10.1037/0022-0167.28.6.545.

Hancock, A., \& Taylor, A. (2019). 'I Am What I Am': Queering career development and practice. In T. Hooley, R. Sultana \& R. Thomsen (Eds.), Career guidance for emancipation: Reclaiming social justice for the multitude (pp. 47-63). Routledge.

Hart, C. S. (2012). Aspirations, education and social justice: Applying Sen and Bourdieu. Continuum International Publishing Group.

Hirschi, A. (2012). The career resources model: An integrative framework for career counsellors. British Journal of Guidance and Counselling, 40(4), 369-383. https://doi.org/10.1080/03069 885.2012.700506.

Hodkinson, P., \& Sparkes, A. C. (1997). Careership: A sociological theory of career decision making. British Journal of Sociology of Education, 18(1), 29-44. https://doi.org/10.1080/0142569970 180102. 
Holmwood, J. (2013). Public reasoning without sociology: Amartya Sen's theory of justice. Sociology, 47(6), 1171-1186. https://doi.org/10.1177/0038038512470767.

Hooley, T. (2014). The evidence base on lifelong guidance. University of Jyväskylä - European Lifelong Guidance Policy Network (ELGPN).

Hooley, T., \& Sultana, R. G. (2016). Career guidance for social justice. Journal of the National Institute for Career Education and Counselling, 36(1), 2-11. https://doi.org/10.20856/jnicec.3601.

Hooley, T., Sultana, R., \& Thomsen, R. (2017). The neoliberal challenge to career guidance-Mobilising research, policy and practice around social justice. In T. Hooley, R. Sultana, \& R. Thomsen (Eds.), Career guidance for social justice: Contesting neoliberalism (pp. 1-28). Routledge.

Hooley, T., Sultana, R. G., \& Thomsen, R. (2019). Towards an emancipatory career guidance: What is to be done? In T. Hooley, R. Sultana, \& R. Thomsen (Eds.), Career guidance for emancipation: Reclaiming Social justice for the multitude (pp. 247-257). Routledge.

Irving, B. A. (2004). Social justice: A context for career education and guidance. In Irving, B. A., \& Malik, B. (Eds.) Critical reflections on career education and guidance: Promoting social justice within a global economy (pp.10-24). Routledge.

Irving, B. A. (2017). The pervasive influence of neoliberalism on policy guidance discourses in career/education: Delimiting the boundaries of social justice in New Zealand. In T. Hooley, R. Sultana, \& R. Thomsen (Eds.), Career guidance for social justice: Contesting neoliberalism (pp. 47-62). Routledge.

Irving, B. A. (2020/forthcoming). The positioning of social justice: Critical challenges for career development. In P. J. Robertson, T. Hooley, \& P. McCash (Eds.), The Oxford handbook of career develoment. Oxford University Press.

Iversen, V. (2003). Intra-household inequality: A challenge for the capability approach? Feminist Economics, 9(2-3), 93-115. https://doi.org/10.1080/1354570032000080868.

Joncas, J. A., \& Pilote, A. (2018). The capability approach in guidance counselling: An innovative, respectful and empowering approach to work with disadvantaged groups. Gottenberg, Sweden: Presentation at International Association for Educational and Vocational Guidance Annual Congress.

Kelly, A. (2012). Sen and the art of educational maintenance: Evidencing a capability, as opposed to an effectiveness, approach to schooling. Cambridge Journal of Education, 42(3), 283-296. https://doi.org/10.1080/0305764X.2012.706255.

Kenny, M. E., Blustein, D. L., Liang, B., Klein, T., \& Etchie, Q. (2019). Applying the psychology of working theory for transformative career education. Journal of Career Development, 46(6), 623-636. https://doi.org/10.1177/0894845319827655.

Killeen, J. (1996). Evaluation. In A. G. Watts, B. Law, J. Killeen, J. M. Kidd, \& R. Hawthorn (Eds.), Rethinking career education and guidance (pp. 331-348). Routledge.

Killeen, J., \& Kidd, J. M. (1991). Learning outcomes of guidance: A review of research. Research Paper No. 85. Employment Department.

Kittay, E. F. (2001). A feminist public ethic of care meets the new communitarian family policy. Ethics, 111(3), 523-547. https://doi.org/10.1086/233525.

Kremakova, M. I. (2013). Too soft for economics, too rigid for sociology, or just right? The productive ambiguities of Sen's capability approach. European Journal of Sociology, 54(3), 393-419. https://doi.org/10.1017/S0003975613000210.

McMahon, M., \& Patton, W. (2018). Systemic thinking in career development theory: Contributions of the systems theory framework. British Journal of Guidance and Counselling, 46(2), 229240. https://doi.org/10.1080/03069885.2018.1428941.

Newman, A., Bimrose, J., Nielsen, I., \& Zacherd, H. (2018). Vocational behavior of refugees: How do refugees seek employment, overcome work-related challenges, and navigate their careers? Journal of Vocational Behavior, 105(April 2018), 1-5. https://doi.org/10.1016/j.jvb.2018.01.007

Norwich, B. (2014). How does the capability approach address current issues in special educational needs, disability and inclusive education field? Journal of Research in Special Educational Needs, 14(1), 16-21. https://doi.org/10.1111/1471-3802.12012.

Nussbaum, M. (2003). Capabilities as fundamental entitlements: Sen and social justice. Feminist Economics, 9(2-3), 33-59. https://doi.org/10.1080/1354570022000077926.

Nussbaum, M. (1997). Capabilities and human rights. Fordham Law Review, 66(1997-1998), 273300. https://ir.lawnet.fordham.edu/flr/vol66/iss $2 / 2$

Nussbaum, M. (2000). Women and human development: The capabilities approach. Cambridge University Press. 
Orton, M. (2011). Flourishing lives: The capabilities approach as a framework for new thinking about employment, work and welfare in the 21st century. Work, Employment and Society, 25(2), 352360. https://doi.org/10.1177/0950017011403848.

Otto, H.-U., Atzmüller, R., Berthet, T., Bifulco, L., Bonvin, J.-M., Chiappero-Martinetti, E., Egdell, V., Halleröd, B., Kjeldsen, C. C., Kwiek, M., Schröer, R., Vero, J., \& Zieleńska, M. (Eds). (2015). Facing trajectories from school to work-Towards a capability-friendly youth policy in Europe. Springer.

Otto, H.-U., Egdell, V., Bonvin, J.-M., \& Atzmüller, R. (Eds.) (2017). Empowering young people in disempowering times: Fighting inequality through capability oriented policy. Edward Elgar.

O’Reilly, J., Smith, M., Deakin, S., \& Burchell, B. (2015). Equal pay as a moving target: International perspectives on forty-years of addressing the gender pay gap. Cambridge Journal of Economics, 39(2), 299-317. https://doi.org/10.1093/cje/bev010.

Picard, F., Olympio, N., Masdonati, J., \& Bangali, M. (2015). Justice sociale et orientation scolaire: l'éclairage de l'approche par les "capabilités" d'Amartya Sen. L'Orientation Scolaire et Professionnelle, 44(1), 23-45. https://doi.org/10.4000/osp.4515.

Picard, F. (2019). Career development practices from the capabilities perspective of social justice. In N. Arthur, R. Neault \& M. McMahon (Eds.), Career theories and models at work: Ideas for practice. CERIC.

Plant, P. (2012). Quality assurance and evidence in career guidance in Europe: Counting what is measured or measuring what counts? International Journal for Educational and Vocational Guidance, 12(2), 91-104. https://doi.org/10.1007/s10775-011-9195-2.

Plant, P., \& Haug, E. H. (2018). Unheard: The voice of users in the development of quality in career guidance services. International Journal of Lifelong Education, 37(3), 372-383. https://doi. org/10.1080/02601370.2018.1485058.

Plant, P., \& Kjærgård, R. (2016). From mutualism to individual competivieness: Implications and challenges for social justice within career guidance in neoliberal times. Journal of the National Institute for Career Education and Counselling, 36(1), 12-19. https://doi.org/10.20856/jnicec.3602

Pogge, T. W. (2002). Can the capability approach be justified? Philosophical Topics, 30(2), 167-228. https://www.jstor.org/stable/43154399

Pryor, R. (2016). Applying chaos theory to work: The chaos theory of careers. International Journal of Mathematics, Game Theory, and Algebra, 25 (4), 369-382. https://search.proquest.com/docvi ew/1931512703/fulltext/44D3F04D436544A8PQ/1 ?accountid=11774

Qizilbash, M. (2011). Sugden's critique of Sen's capability approach and the dangers of libertarian paternalism. International Review of Economics, 58(1), 21-42. https://doi.org/10.1007/s1223 2-011-0112-2.

Rawls, J. (1999). A theory of justice. Revised Edition. The Belknap Press of Harvard University Press.

Richardson, M. S. (2009). Another way to think about the work we do: Counselling for work and relationship. International Journal for Educational and Vocational Guidance, 9(2), 75-84. https://doi. org/10.1007/s10775-009-9154-3.

Roberts, K. (2005). Social class, opportunity structures and career guidance. In B. Irving \& B. Malik (Eds.), Critical reflections on career education and guidance: Promoting social justice within a global economy (pp. 130-142). Routledge.

Roberts, K. (2009). Opportunity structures then and now. Journal of Education and Work, 22(5), 355368. https://doi.org/10.1080/13639080903453987.

Robertson, P. J. (2015). Towards a capability approach to careers: Applying Amartya Sen's thinking to career guidance and development. International Journal for Educational and Vocational Guidance, 15, 75-88. https://doi.org/10.1007/s10775-014-9280-4.

Robertson, P. J., \& Egdell, V. (2018). A capability approach to career development: An introduction and implications for practice. Australian Journal of Career Development, 27(3), 119-126. https://doi. org/10.1177/1038416217704449.

Robeyns, I. (2005). The capability approach: A theoretical survey. Journal of Human Development, 6(1), 93-117. https://doi.org/10.1080/146498805200034266.

Robeyns, I. (2008). How has the capability approach been put into practice. E- Bulletin of the Human Development and Capability Association, 12.

Roemer, J. E. (1996). Equality versus progress. Nordic Journal of Political Economy, 23(1996), 47-54. http://www.nopecjournal.org/NOPEC_1996_a03.pdf

Saito, M. (2003). Amartya Sen's capability approach to education: A critical exploration. Journal of Philosophy of Education, 37(1), 17-33. https://doi.org/10.1111/1467-9752.3701002. 
Savickas, M. L., Nota, L., Rossier, J., Dauwalder, J.-P., Duarte, M. E., Guichard, J., Soresi, S., Van Esbroek, R., \& Van Vianen, A. E. M. (2009). Life designing: A paradigm for career construction in the 21st century. Journal of Vocational Behavior, 75(3), 239-250. https://doi.org/10.1016/j. jvb.2009.04.004.

Sayer, A. (2012). Capabilities, contributive injustice and unequal divisions of labour. Journal of Human Development and Capabilities, 13(4), 580-596. https://doi.org/10.1080/19452829.2012.693069.

Schein, E. H. (1990). Career anchors: Discovering your real values. Jossey-Bass/Pfeiffer.

Sen, A. (1985). Well-being, agency and freedom: The Dewey lectures 1984. The Journal of Philosophy, 82(4), 169-221. https://doi.org/10.2307/2026184.

Sen, A. (1987). Gender and cooperative conflicts. World Institute for Development Economics Research.

Sen, A. (1990). Justice: Means versus freedoms. Philosophy and Public Affairs, 19(2), 111-121. https:// www.jstor.org/stable/2265406

Sen, A. (1999). Development as Freedom. Knopf Press.

Sen, A. (2003). Inequality reexamined. Oxford Scholarship Online. https://doi.org/10.1093/0198289286 .001 .0001 .

Sen, A. (2009). The idea of justice. Penguin.

Sevenhuijsen, S. (1998). Citizenship and the ethics of care: Feminist considerations on justice, morality and politics. Routledge.

Skovhus, R. B. (2016). A focus on educational choice has social justice consequences-An empirical study informed by Sen's capability approach. Journal of the National Institute for Career and Educational Counselling, 36(1), 54-60. https://doi.org/10.20856/jnicec.3607

Srinivasan, T. N. (1994). Human development: A new paradigm or reinvention of the wheel? American Economic Review Papers and Proceedings, 84(2), 238-243. https://www.jstor.org/stable/2117836

Sugden, R. (2006). What we desire, what we have reason to desire, whatever we might desire: Mill and Sen on the value of opportunity. Utilitas, 18(01), 33. https://doi.org/10.1017/S0953820805001810.

Sultana, R. G. (2014). Pessimism of the intellect, optimism of the will? Troubling the relationship between career guidance and social justice. International Journal for Educational and Vocational Guidance, 14(1), 5-19. https://doi.org/10.1007/s10775-013-9262-y.

Super, D. E. (1957). The psychology of careers. Harper \& Row.

Thomsen, R. (2012). Career guidance in communities. Aarhus University Press.

Thomsen, R. (2016). The practice portrait-A method for promoting social justice in practice. Journal of the National Institute for Career Education and Counselling, 36(1), 30-37. https://doi. org/10.20856/jnicec.3604

Verd, J. M., \& Andreu, M. L. (2011). The rewards of a qualitative approach to life-course research. the example of the effects of social protection policies on career paths. Forum Qualitative Sozialforschung / Forum: Qualitative Social Research. https://doi.org/10.17169/FQS-12.3.1753

Walby, S. (2012). Sen and the measurement of justice and capabilities. Theory, Culture and Society, 29(1), 99-118. https://doi.org/10.1177/0263276411423033.

Watts, A. G., \& Sultana, R. (2004). Career guidance policies in 37 countries: Contrasts and common themes. International Journal for Vocational and Educational Guidance, 4(2-3), 105-122. https:// doi.org/10.1007/s10775-005-1025-y.

Willis, P. E. (1977). Learning to labour: How working class kids get working class jobs. Gower.

Wright, S. (2016). Conceptualising the active welfare subject: Welfare reform in discourse, policy and lived experience. Policy and Politics, 44(2), 235-252. https://doi.org/10.1332/030557314X13904 856745154.

Yilmaz, E. (2016). Resources versus capabilities in social justice. Journal of Interdisciplinary Economics, 28(2), 230-254. https://doi.org/10.1177/0260107916643588.

Zimmermann, B. (2006). Pragmatism and the capability approach: Challenges in social theory and empirical research. European Journal of Social Theory, 9(4), 467-484. https://doi.org/10.1177/13684 31006073014.

Publisher's Note Springer Nature remains neutral with regard to jurisdictional claims in published maps and institutional affiliations. 